\title{
TYPE E BOTULISM: A HAZARD OF THE NORTH
}

\author{
Claude E. Dolman*
}

$\mathbf{I}^{1}$

N 1908, on returning after two years' absence to the head of the Mackenzie Delta, the explorer Stefansson (1929) learned that many of his Eskimo acquaintances were dead, including a group of eight "poisoned by eating the meat of a freshly killed white whale." Calamities of that sort were familiar to whalers and attributed by them to ptomaine poisoning; but Stefansson concluded this could scarcely be the cause, as he had seen tons of semi-decayed whale meat eaten without harm. He appears to have been the first to suggest that these mysterious fatalities might be due to trichinosis (Stefansson 1914).

Twenty years later, Parnell (1934) also referred to "deaths of whole families which are periodically reported among the Eskimos." These were "always ascribed to 'ptomaine poisoning': without, however, any real evidence." Apparently unaware of Stefansson's prediction, Parnell speculated that the "Trichina worm", whose presence he had noted in arctic foxes and polar bears in the eastern Canadian Arctic, could be responsible for such deaths. These conjectures were later rendered plausible by parasite surveys of the fauna conducted by Thorborg et al. (1948) in Western Greenland, by Brown et al. (1949) in the Northwest Territories, and by Brandly and Rausch (1950) in Alaska, which established that Trichinella spiralis has a holarctic distribution. Connell (1949), in his review of the problem, indicates that the sled dog, and also certain wild carnivores, particularly the polar bear and the arctic fox, are liable to be infested; and that occasionally such marine mammals as the white whale (beluga), the walrus, and the bearded seal, somehow become hosts to Trichinella. There is now plenty of evidence that human trichinosis can occur in the Far North through consumption of the raw or inadequately cooked flesh of many of the above species.

Without minimizing the seriousness of this risk of trichinosis, the present report draws attention to botulism as the probable explanation of many of the outbreaks of fatal poisonings to which Stefansson and Parnell referred. As the food habits of the natives of certain arctic and subarctic

*Dept. of Bacteriology and Immunology, Univ. of British Columbia, Vancouver, B.C. and Connaught Medical Research Laboratories, Univ. of Toronto (Western Division). 
regions are very conducive to botulism, its control is mainly a problem of education in public health. Among Eskimos, the implicated foods have been raw or preserved products of marine mammals, particularly the white whale and seal; whereas raw salmon eggs prepared in various insanitary ways have caused several outbreaks among the Indians of the northern Pacific Coast. Enough of these occurrences have now been investigated bacteriologically to justify the claim that type $\mathrm{E}$ botulism is especially liable to be involved.

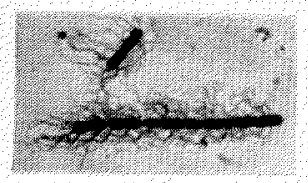

a

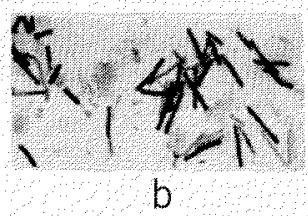

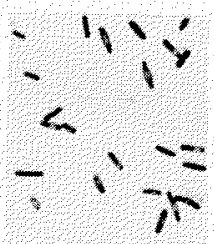

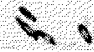

C

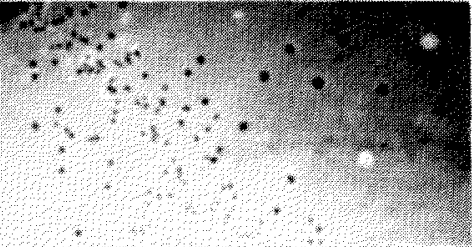

d $\times 4$

$\times 1200$

Fig. 1. Clostridium botulinum type $\mathrm{E}$ isolated from Alaskan Eskimo outbreaks.

(a), (b), and (c), from beluga flipper ("muktuk"), Point Hope, 1950.

(d), from grey whale fluke, Scammon Bay, 1959.

a. Short-chained and individual bacilli stained to show numerous peritrichous flagella (x 1200).

b. Toxic culture, Gram-stained, showing ghost forms, no spores (x 1200).

c. Atoxic, sporulating mutant culture (x 1200).

d. Mixed culture plated on blood agar and incubated anaerobically for 24 hours at $30^{\circ} \mathrm{C}$. The minute, translucent type $\mathrm{E}$ colonies are surrounded by circular areas of haemolysis ( $x 4)$.

\section{Definition, symptomatology and pathogenesis of type $E$ botulism}

Botulism may be defined as a serious and often fatal form of bacterial intoxication, affecting man and animals, which generally results from the ingestion of foodstuffs wherein Clostridium botulinum, a sporulating, anaerobic, motile bacillus has proliferated and produced a powerful neuroparalytic exotoxin (Fig. 1). There are at least 5 types of $\mathrm{Cl}$. botulinum, designated alphabetically from A to E. They manufacture pharmacologically similar but immunologically distinct toxins, to which different animal species show varying degrees of susceptibility. Human botulism is nearly always due to type $\mathrm{A}, \mathrm{B}$ or $\mathrm{E}$.

Botulism and trichinosis are both endemic hazards of the Arctic, where the uncooked flesh of mammals may serve as vehicles for either disease; but they show few other resemblances. The two conditions differ importantly even in respect of the shared features. Trichinosis has a circumpolar distribution, whereas botulism has not been reported from Greenland or 
from the far north of Scandinavia and Siberia. The largest recorded epidemic of arctic trichinosis, which occurred in West Greenland in 1947, was ascribed to walrus meat by Thorborg et al. (1948); but the possibility that dog flesh was actually to blame has been stressed recently by Fay (1960). In any event, sea mammals are seldom implicated in human outbreaks of this disease, whose most dangerous vehicle is apparently polar bear. By contrast, all known outbreaks of botulism in the Arctic have been attributed to food products of whales and seals, while type E botulism has never been traced to consumption of terrestrial carnivores.

The finer points of differential diagnosis between these diseases need not be considered here, but the following outline of their symptomatology and pathogenesis should enable even laymen to distinguish them. In trichinosis, the symptoms are extremely variable, because the larvae of Tr. spiralis may invade and become encysted in many tissues and organs, with a predilection for the musculature. However, two phases, intestinal and invasive, can generally be discerned. In the first week after infested meat has been swallowed, the encysted larvae are liberated into the bowel lumen, where most of them develop within a few days into mature adults. The viviparous females burrow into the intestinal mucosa, whence each emits some thousands of larvae. During this phase, which is often of 2 to 3 weeks duration, the main symptoms are abdominal - nausea, vomiting, diarrhoea, pain, and even intestinal haemorrhages, associated with fever suggesting some form of gastroenteritis. Such troubles may be evanescent, or obscured by the early onset of symptoms referable to larval migration and invasion.

The young larvae find their way through the walls of intestinal lymphatics and veins, whence they are conveyed by the general circulation to all parts of the body, especially the skeletal muscles, diaphragm, and heart. In this phase, which usually lasts from the second to the sixth or seventh week of illness, prominent symptoms are muscle pains, swelling of face and eyelids, fever, and rash. In severe cases, stiffness of the trunk and limbs develop around the fifth week, followed sometimes by delirium, stupor, and coma as forerunners of death. The mortality rate in epidemics has ranged from 5 to 30 per cent. In the Greenland outbreak, about 300 persons were affected, and 33, or 11 per cent, died (Thorborg et al, 1948).

In botulism the incubation period is much shorter, usually 8 to 20 hours. Abdominal symptoms - nausea, vomiting, pain, and distension may develop within a few hours after the meal, being followed generally by persistent constipation, and by the onset of a peculiar paralytic syndrome. When sufficient toxin has been absorbed from the stomach and intestines to reach sites adjacent to cranial and peripheral motor nerve endings, it exerts an inhibitory effect upon the mechanism of acetylcholine synthesis or release, thus interfering with the transmission of neural impulses to muscles and glands. Frequently, the cranial nerves supplying the muscles of the eye and throat are affected first, leading to dim, fuzzy, or double vision, loss of pupillary reflexes, and difficulty in swallowing or 
speaking. This is accompanied or followed by generalized weakness, and in severe cases by respiratory and cardiac failure. Dryness of the mouth is often a troublesome feature. There is no rash, no fever, and consciousness is seldom impaired, even in the terminal stages. In fatal cases death generally ensues between the second and fifth days, but may occur as early as 20 to 24 hours, or as late as 10 to 14 days, after consumption of the botulogenic focd. The fatality rates for type $\mathrm{E}$ botulism have ranged between 32 and 72 per cent in different parts of the world.

In 1932 an outbreak of botulism at Cooperstown, N.Y. (MacKenzie 1934), was eventually proved by Hazen (1938) to have been caused by one of the recently discovered type $\mathrm{E}$ cultures of $\mathrm{Cl}$. botulinum. Including this first recognized type $E$ episode, there have been to date at least 50 recorded occurrences in several countries, affecting 242 persons, of whom 85 died, a case fatality rate of 35.1 per cent. Table 1 shows that type $\mathrm{E}$ botulism has been confined mainly to Japan, Canada, and the United States, with single instances at Leningrad, U.S.S.R., in 1938, and at Frederiksberg, Denmark, in 1951. Excluding 3 outbreaks in the U.S.A. and a recent one in Canada attributed to imported focds, there remain 46 occurrences, all in northerly latitudes, in which fish, fish eggs, or marine mammals of local origin were invariably the vehicles. The exceptions are 2 episodes in the state of New York, due respectively to Labrador salmon and canned sprats from Germany; one in California attributed to mushrooms from Jugoslavia; and one in British Columbia due to salted herrings from Holland.

Table 1. Geographic distribution of type $\mathbf{E}$ botulism outbreaks.

\begin{tabular}{|c|c|c|c|c|}
\hline \multicolumn{2}{|c|}{ Place of occurrence } & Outbreaks & Cases & Deaths \\
\hline JAPAN: & Hokkaido & 19 & 137 & 39 \\
\hline CANADA. & Northern Honshu & 13 & 50 & 21 \\
\hline CANADA: & $\begin{array}{l}\text { British Columbia } \\
\text { Labrador }\end{array}$ & $\begin{array}{l}6 \\
i\end{array}$ & $\begin{array}{r}13 \\
8\end{array}$ & 9 \\
\hline U.S.A.: & Alaska & 6 & 18 & 6 \\
\hline & New York & 2 & 6 & 2 \\
\hline USSR & California & 1 & 3 & 1 \\
\hline DENMÄRK: & Frederiksberg & 1 & 6 & 0 \\
\hline & TOTALS & 50 & 242 & 85 \\
\hline
\end{tabular}

Overall case fatality rate, 35.1 per cent.

The chief factors governing these peculiar relationships have been analyzed and discussed in previous reports (Dolman and Chang 1953; Dolman 1957a, 1957b), and may be summarized as follows: (1) A relatively heavy dissemination of Clostridium botulinum type $\mathbf{E}$ spores in the soil, off-shore waters, and sea mud of certain regions in the Northern Hemisphere. (2) The liability of fish and sea mammals to ingest these spores while feeding, or to become contaminated with them at skin apertures and in wounds. (3) The capacity of the spores, after death of the host and under favourable temperature conditions, to vegetate, to migrate from the gut or 
integuments into the muscles, and there to proliferate and manufacture toxin. (4) The unusually low thermal resistance of most type $\mathrm{E}$ spores, which precludes their survival in well-cooked foods. (5) The eating habits of the native populations of certain northern areas, who customarily consume marine products raw or only lightly cooked.

\section{Epidemiology and geographic distribution of type $\mathbf{E}$ botulism outbreaks}

The first and last of the foregoing factors mainly determine the regional distribution of type $\mathrm{E}$ botulism. The incidence will be high where both these prerequisites are present in full measure, as they are in parts of northern Japan and the British Columbian coast. A similar combination of circumstances presumably obtains in those areas of Alaska, the Northwest Territories, and Labrador, where food habits of the Eskimos make botulism possible, and where the occurrence of outbreaks of type $\mathrm{E}$ botulism points to the probable existence of type $\mathrm{E}$ spores in these localities. In an attempt to verify this probability, it is planned to examine bacteriologically samples of sea-bottom mud and shore-line silt from the Canadian Arctic and Alaska.

Type E spores are evidently present also in certain parts of Europe, such as southern Russia, northern France, and Denmark, but seem to be more thinly scattered there than in the above areas.

\section{Northern Japan}

Japan was free of recorded botulism until 1951, since when there have been 32 type $\mathrm{E}$ outbreaks, all fish-borne, affecting 187 persons, of whom 60 died, a case fatality rate of 32.1 per cent. The areas of endemicity lie between latitudes $40^{\circ}$ and $46^{\circ} \mathrm{N}$. Hokkaido, the northernmost and least densely populated island (about 4 million inhabitants), has experienced 19 of these outbreaks, affecting 137 among 288 persons at risk, with 39 deaths (Nakamura et al. 1956; Iida et al. 1958; Iida 1959, 1960). One outbreak was due to trout eggs, and the other 18 to home-made "izushi" - a relish made from raw fish, rice, and diced vegetables, pressed and fermented together in a wooden tub for periods ranging from a few days to 3 or 4 weeks. The fish most often used in the preparation of toxic "izushi" have been locally caught, bottom-feeding species, such a sole, carp, common goby, and sandfish; but in some outbreaks, predatory species such as horse-mackerel were implicated.

Since 1953, an adjacent area of northwestern Honshu has experienced at least 13 type $\mathrm{E}$ outbreaks, affecting 50 persons with 21 fatalities. Twelve of these were again due to "izushi", and one to canned mackerel. Apart from these proven outbreaks, Saito and Fujisawa (1956), and Yamamoto (1960) have traced 10 other "izushi"-borne outbreaks of botulism, involving 42 cases with 19 fatalities, which occurred within the same regions during the period 1930-52, but were not bacteriologically investigated. 
Saito and Fujisawa (1956) and Nakamura et al. (1956) isolated type E cultures from intestinal samples of fish caught in the foregoing areas. They also found similar organisms in samples of coastal sand and of lake-shore and lake-bottom mud collected in vicinities where type $\mathrm{E}$ outbreaks had occurred. These observations suggest that the fish used for "izushi" could have become contaminated either by their intestinal flora when they were gutted and soaked in water, or through traumatic and telluric exposure after capture.

\section{British Columbia, Yukon, and southeastern Alaska}

Since 1940 , on the other side of the northern Pacific Ocean, there have been at least 12 comparable outbreaks of botulism due to locally caught fish or their products. In another episode the implicated fish originated several thousands of miles away. Altogether, 25 persons were affected, of whom 18, or 72 per cent, died. (Table 2, Fig. 2).

Table 2. Fish-borne botulism outbreaks in British Columbia, Yukon and southeastern Alaska.

\begin{tabular}{|c|c|c|c|c|c|}
\hline $\begin{array}{c}\text { Place of } \\
\text { occurrence }\end{array}$ & $\begin{array}{l}\text { Date of } \\
\text { occurrence }\end{array}$ & Cases & Deaths & $\begin{array}{l}\text { Foodstuff } \\
\text { implicated }\end{array}$ & $\begin{array}{c}\text { Type } \\
\text { involved }\end{array}$ \\
\hline $\begin{array}{l}\text { Nr. Whitehorse, Yukon } \\
\text { Nanaimo, B.C. } \\
\text { Ketchikan, Alaska } \\
\text { Vancouver, B.C. } \\
\text { Natal, B.C. } \\
\text { Bella Bella, B.C. } \\
\text { Prince Rupert, B.C. } \\
\text { Port Edward, B.C. } \\
\text { Hydaburg, Alaska } \\
\text { Hydaburg, Alaska } \\
\text { Penticton, B.C. } \\
\text { Ketchikan, Alaska }\end{array}$ & $\begin{array}{l}\text { Aug. } 1940 \\
\text { Sept. } 1944 \\
\text { Aug. } 1948 \\
\text { Oct. } 1949 \\
\text { Sept. } 1952 \\
\text { Nov. } 1954 \\
\text { Aug. } 1957 \\
\text { July } 1958 \\
\text { Aug. } 1958 \\
\text { Sept. } 1959 \\
\text { Mar. } 1960 \\
\text { Aug. } 1960\end{array}$ & $\begin{array}{l}5 \\
3 \\
2 \\
2 \\
1 \\
3 \\
3 \\
1 \\
1 \\
1 \\
1 \\
2\end{array}$ & $\begin{array}{l}3 \\
3 \\
1 \\
1 \\
1 \\
1 \\
3 \\
1 \\
1 \\
1 \\
0 \\
2\end{array}$ & $\begin{array}{l}\text { Salmon eggs } \\
\text { Home-canned salmon } \\
\text { Salmon eggs } \\
\text { Home-pickled herring } \\
\text { Home-pickled trout } \\
\text { Salmon egg "cheese" } \\
\text { Chum salmon eggs } \\
\text { Spring salmon eggs } \\
\text { Salmon eggs } \\
\text { Salmon eggs } \\
\text { Salted Holland herring } \\
\text { Salmon egg "cheese" }\end{array}$ & $\begin{array}{l}? \\
\stackrel{?}{\mathrm{E}} \\
? \\
\stackrel{\mathrm{E}}{\mathrm{E}} \\
\mathrm{E} \\
\mathrm{E} \\
\mathrm{E} \\
\mathrm{B} \\
? \\
\stackrel{\mathrm{E}}{\mathrm{E}} \\
\mathrm{E}\end{array}$ \\
\hline
\end{tabular}

Total cases 25 ; total deaths 18 ; case fatality rate 72 per cent.

Four type $\mathbf{E}$ outbreaks took place in southern British Columbia, at latitudes between $49^{\circ}$ and $50^{\circ} \mathrm{N}$. Of these, two occurred in coastal cities, at Nanaimo (Dolman and Kerr 1947) and Vancouver (Dolman et al. 1950); one at Natal, a rural community nearly 400 miles inland (Dolman 1953); and the other at Penticton, a city about 160 miles from the coast (Dolman 1961). The vehicles were home-canned salmon, home-pickled herring, home-pickled river trout, and imported salt herring.

The remaining 8 outbreaks, which occurred at latitudes ranging from $52^{\circ}$ to $63^{\circ} \mathrm{N}$., included 4 due to type $\mathrm{E}$ toxin and 1 to type $\mathrm{B}$; in 3 others no bacteriological tests were made. Seven took place in coastal towns or settlements in northern British Columbia and southern Alaska, and the other on the Yukon River about 100 miles downstream from Whitehorse, Y.T. In each the vehicle was salmon eggs and the victims were Indians (Dolman et al. 1960, Williams 1960). Of the 18 persons affected, 13 died. 
The high case fatality rate in this series of outbreaks - double the Japanese rate - is probably due partly to incomplete reporting of illness among Indians of the northern Pacific Coast, and partly to the semi-fluid, proteinaceous nature of fish eggs, which renders them a particularly suitable medium for toxin production. The morbidity rate for botulism in these areas is also considerably higher than in northern Japan, for their total population does not exceed 100,000 (less than one-fortieth that of Hokkaido). This heavy regional incidence can be attributed to the two chief factors cited earlier. The techniques used by the Indians in preparing salmon eggs for human consumption, details of which have been recorded elsewhere (Dolman et al. 1955, 1960), are potentially very botulogenic. Also, spores of toxigenic type $\mathrm{E}$ strains of $\mathrm{Cl}$. botulinum are present in surprisingly large numbers on the ocean floor at various depths in certain localities along the British Columbia coast.

Such spores may survive for many months in samples of sea mud, collected in sterile vials and kept at around $5^{\circ} \mathrm{C}$. For example, one specimen collected at Bute Inlet $\left(50^{\circ} 30^{\prime}\right.$ to $51^{\circ} \mathrm{N}$.) early in July 1955 from a depth of 658 metres yielded a type $\mathrm{E}$ strain in pure culture when examined over 20 months later. Two others were negative. Near the end of 1959, 2 bottom samples taken about 6 months previously from the same inlet at 650 and 350 metres yielded type $\mathrm{E}$ strains, and 1 from 470 metres a type A strain. Botulism has not been reported among the few inhabitants of the vicinity of Bute Inlet, but fish-borne outbreaks have occurred about 125 miles to the south, at Nanaimo and Vancouver, B.C., and also some 175 miles north of the inlet, at Bella Bella, B.C. (Table 2, Fig. 2).

Nine bottom samples collected in shallower waters near Prince Rupert, B.C. during October and December 1959 from a coastal stretch between $53^{\circ} 20^{\prime}$ and $54^{\circ} \mathrm{N}$. yielded 5 strains of $\mathrm{Cl}$. botulinum type $\mathrm{E}$. Three positive samples were collected at depths of 4,22 , and 24 metres, respectively; one came from 6 inches below the surface of the Oona River tide flat; and one from the bottom of the Kumealon River (depth about 1 foot) near the limit of tidal influence. In this general vicinity, at least two botulism outbreaks due to salmon eggs are known to have occurred, one involving 3 type E fatalities in 1957, and the other a single type B fatality in 1958 (Dolman et al. 1960).

Botulinus spores ingested by fish are liable to remain part of their intestinal flora. In fact, the prototype strains of $\mathrm{Cl}$. botulinum type $\mathbf{E}$ were isolated in 1934-35 from the intestines of sturgeon in the Soviet Ukraine (Gunnison et al. 1936), where type A and B strains had been demonstrated earlier in similar fish (Dolman and Chang 1953). Subsequently, type E cultures were obtained from the intestinal contents of one out of 176 fish caught in northern France (Prévot and Huet, 1951); of 10 out of 12 dead fish floating in Hachiro Lagoon, Northern Honshu (Saito and Fujisawa 1955); of an unspecified number caught in Lake Abashiri, Hokkaido (Nakamura et al. 1956); and of a salmon caught in the Strait of Georgia, near Vancouver, B.C. (Dolman 1957b). Such intestinal spores represent 


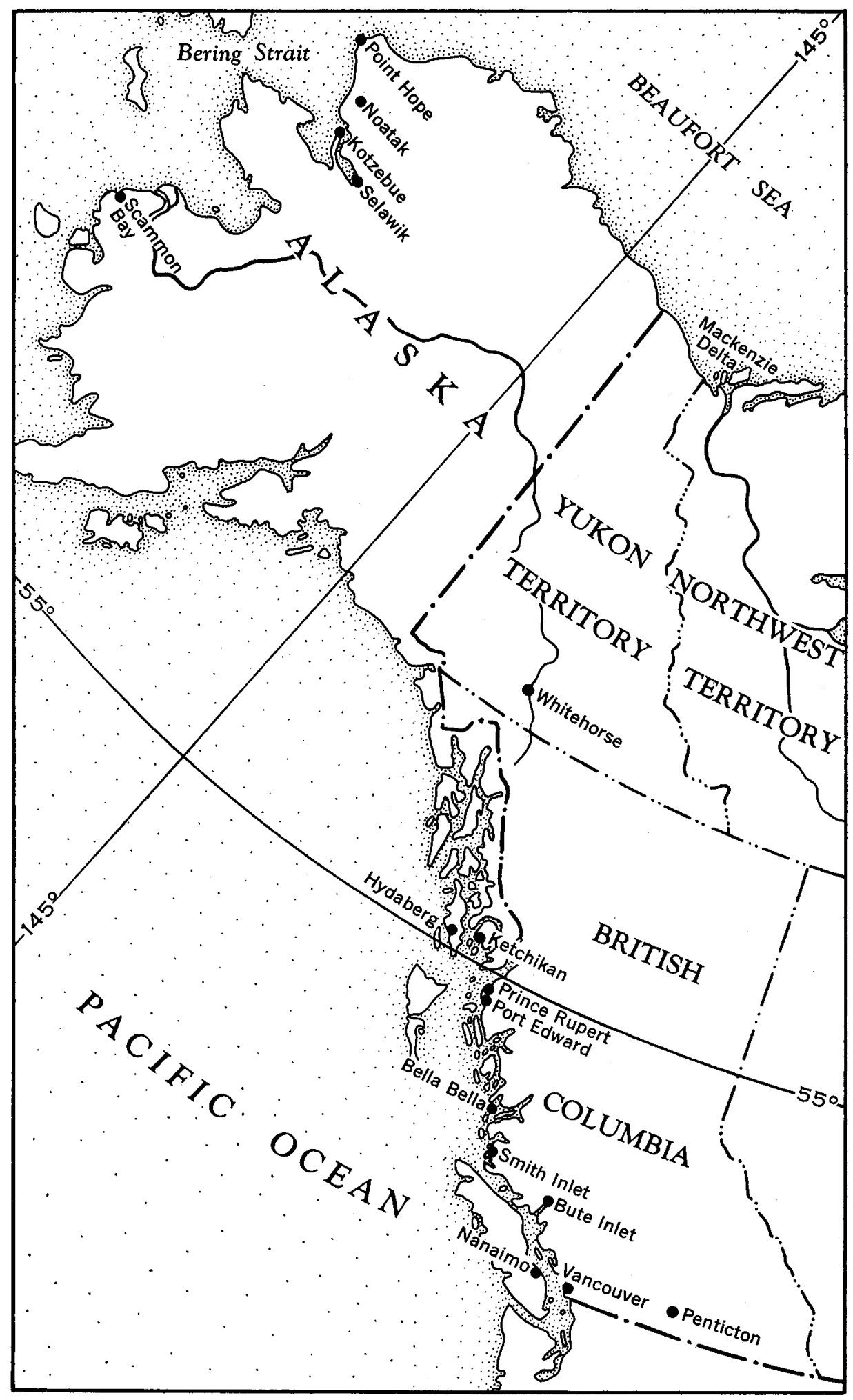

Fig. 2. Sites of botulism occurrences due to uncooked products of fish and marine mammals (and of $\mathrm{Cl}$. botulinum isolations from sea bottom samples) in British Columbia, Alaska, and the Yukon. 
an "endogenous" source of contamination when the fish are gutted or the eggs removed. If these procedures are carried out by persons with hands, utensils, or clothing polluted by fish faeces, the risks of introducing toxigenic spores into edible products are of course increased.

Alternatively, "exogenous" pollution of fish products may occur through direct or indirect contact with soil. Since Meyer and Dubovsky (1922) made their extensive survey of soil samples from various parts of the United States for types A and B botulinus spores, the telluric origin and widespread but erratic distribution of these spores has been generally accepted. Dolman (1957b) postulated that type $\mathrm{E}$ spore dissemination in some off-shore waters and submarine deposits may persist through proliferation of the organisms in the sea mud; but that such foci actually originate in the alluvial soil and terraqueous deposits of the adjacent shore, where in certain areas type $\mathrm{E}$ spores probably outnumber those of other types.

Northern Japan is one such area. Saito and Fujisawa (1956) isolated 18 type E strains from 146 samples of soil or mud taken from 35 locations in or near the Hachiro Lagoon. Nine of these isolates came from 26 specimens of lake bottom mud. Nakamura et al. (1956) isolated 6 type E strains from about 2000 specimens of mud from the shore of Lake Abashiri; and also 2 strains from 50 specimens of sand from the coast facing the Sea of Okhotsk. No cultures of other known botulinus types were identified.

Although there has been no opportunity to verify the possibility that type $\mathrm{E}$ spores predominate in the soil of those coastal areas of British Columbia and southeastern Alaska where fish-borne botulism seems to be endemic, it is noteworthy that $\mathrm{Cl}$. botulinum type $\mathrm{E}$ was first isolated from soil during the investigation of a fatal outbreak of fish-borne botulism at Nanaimo, B.C., in 1945 (Dolman and Kerr 1947).

\section{Outbreaks among Eskimos}

Botulogenic conditions also prevail among the Eskimos of northwestern Alaska, the Northwest Territories, and Labrador, whose well-known liking for raw and parboiled fat and flesh of marine mammals has led to 13 authenticated outbreaks between July 1945 and July 1960 affecting 44 persons, with 23 deaths, i.e. a case fatality-rate of 52.3 per cent. (Table 3 ). In 5 instances, the foodstuff involved was "muktuk", or flippers of beluga (white whale, Delphinapterus leucas) preserved in seal oil; "utjak" (rotting seal flippers) was implicated on 3 occasions, and dried seal meat twice; seal liver, and fluke of the grey whale, Eschrichtius glaucus, were each responsible once.

The first 3 and the latest 2 outbreaks were not bacteriologically investigated. In 2 other recent episodes, the only specimens available for examination were a piece of human liver and stomach washings, respectively, which gave no significant results. Of 6 samples of implicated food remnants sent to the laboratory, 5 yielded type $\mathrm{E}$ strains of $\mathrm{Cl}$. botulinum and the other a type A strain. 
Table 3. Botulism outbreaks from consumption of marine mammals by Eskimos in Alaska, Northwest Territories and Labrador.

\begin{tabular}{lccclc}
\hline \multicolumn{1}{c}{$\begin{array}{c}\text { Place of } \\
\text { occurrence }\end{array}$} & $\begin{array}{c}\text { Date of } \\
\text { occurrence }\end{array}$ & Cases & Deaths & $\begin{array}{c}\text { Foodstuff } \\
\text { implicated }\end{array}$ & $\begin{array}{c}\text { Type } \\
\text { involved }\end{array}$ \\
\hline Markham Bay, N.W.T. & July 1945 & 8 & 7 & Seal meat & $?$ \\
Kotzebue, Alaska & July 1947 & 3 & 2 & Beluga flippers & Beluga flippers \\
Noatak, Alaska & Aug. 1948 & 2 & 1 & Beluga flippers & $?$ \\
Point Hope, Alaska & Aug. 1950 & 5 & 0 & Beluga \\
Selawik, Alaska & July 1952 & 1 & 1 & Beluga flippers & E \\
Kotzebue, Alaska & Aug. 1956 & 2 & 1 & Beluga flippers & E \\
Ungadlek, Labrador & Dec. 1956 & 8 & 6 & Seal flippers & E \\
Scammon Bay, Alaska & Oct. 1959 & 7 & 1 & Grey whale fluke & E \\
Hopedale, Labrador & May 1960 & 4 & 2 & Seal flippers & $?$ \\
Hopedale, Labrador & June 1960 & 1 & 1 & Seal liver & A \\
Nr. Hopedale, Labrador & June 1960 & 1 & 1 & Dried seal meat & $?$ \\
Nr. Hopedale, Labrador & July 1960 & 1 & 0 & Dried seal meat & $?$ \\
Nain, Labrador & July 1960 & 1 & 0 & Seal flippers & $?$ \\
\hline
\end{tabular}

Total cases 44 ; total deaths 23 ; case fatality rate 52.3 per cent.

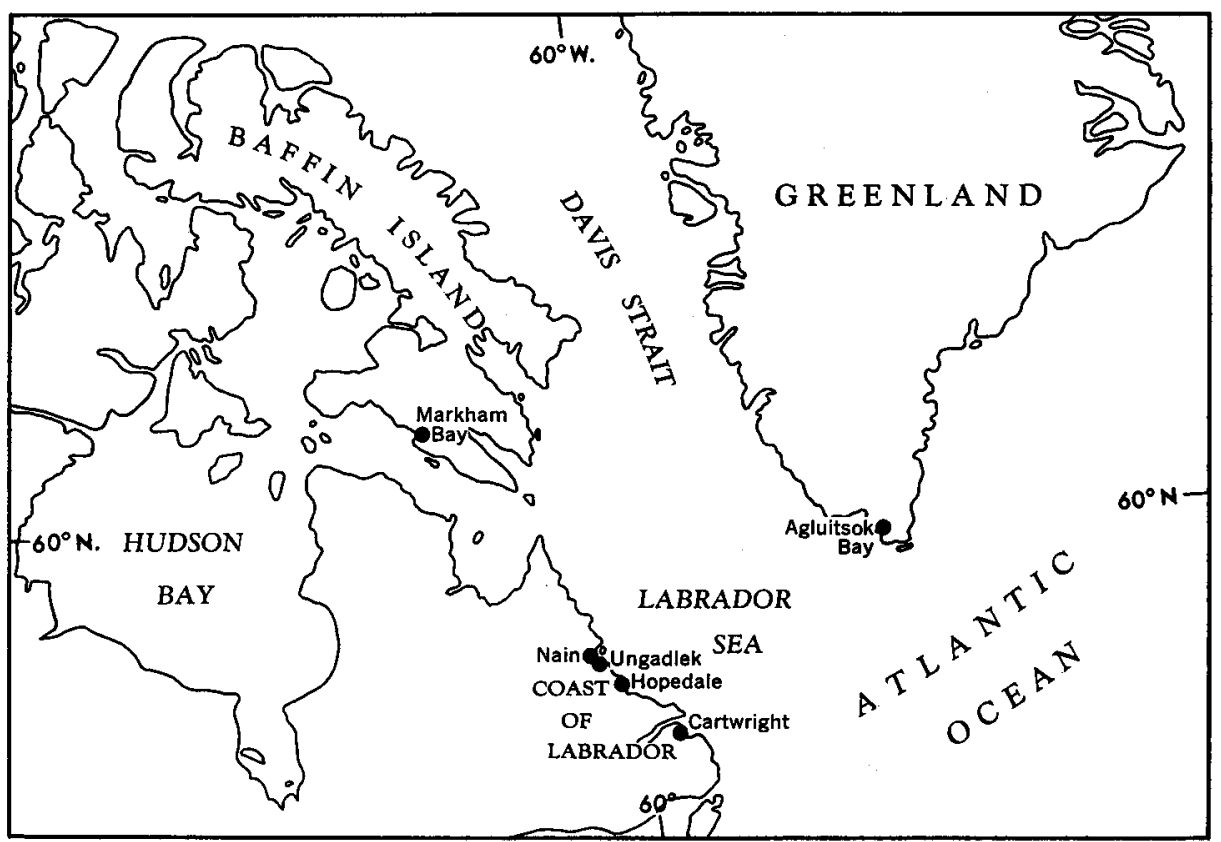

Fig. 3. Sites of botulism outbreaks in Northwest Territories and Labrador. The salmon responsible for the first known type $\mathbf{E}$ outbreak was probably caught and smoked at Cartwright. Cl. botulinum type $\mathbf{E}$ was isolated from a sea bottom sample dredged at 350-400 m. depth from Agluitsok Bay, Greenland.

Markham Bay, N.W.T. Early in July 19457 Eskimos died after eating raw or parboiled seal meat in a camp numbering 23 men, women, and children, at Markham Bay, N.W.T. (roughly $63^{\circ} 30^{\prime}$ N. $71^{\circ}$ W., Fig. 3). Three adults, including the head man, and 5 children aged 7 to 15 years, were 
affected by a syndrome which was unmistakably botulinic. An 8-year-old boy was the only survivor. Most of the victims lived in one tent and had eaten nothing but seal meat, sliced from a carcass kept unskinned on the ground inside the tent (Dolman 1953).

In the Canadian Eastern Arctic several seal carcasses are piled sometimes on the shore for 2 to 3 days before being skinned and eviscerated by their owners, when the offal is thrown to the dogs. In other Eskimo camps, the carcasses are kept together in the head man's tent for distribution later. Thus there are many opportunities for endogenous (intestinal) or exogenous (telluric) contamination of a seal carcass; and since no attempt is made to keep it frozen, a few days of mild weather might suffice to ensure production of lethal amounts of toxin in some parts of the meat.

Point Hope, Kotzebue, and Scammon Bay, Alaska. During the past 10 or 12 years several outbreaks of botulism have affected Eskimos inhabiting the coastal strip of northwestern Alaska between latitudes $62^{\circ}$ and $68^{\circ} \mathrm{N}$. (Fig. 2). The vehicle has generally been "muktuk", an Eskimo delicacy prepared by cutting the skin and underlying blubber of beluga flippers into chunks or strips that are dried on a rack for a period of 1 to 10 days. The pieces are then cured in a barrel of seal oil for at least 4 to 6 weeks, and sometimes for several months, in the comparative warmth of the hut (Rabeau 1960).

In 1947 and 1948, some deaths from botulism supposedly occurred at Point Hope, situated on the Arctic Ocean at approximately $68^{\circ} \mathrm{N} .167^{\circ} \mathrm{W}$., but as no details are available these outbreaks have not been included in Table 3. Late in August 1950 in the same locality, 5 members of a family of Eskimos aged 18 to 62 years developed mild botulism, from which they all recovered, after eating "muktuk" (Meyer and Eddie 1951). A sample of flipper was found to contain about 4 mouse minimal lethal doses (MLD) of type $\mathrm{E}$ toxin per gram, but the causal microorganism was not isolated (Meyer 1950). From a decomposed remnant sent to the author a few months later, a strain of $\mathrm{Cl}$. botulinum type $\mathrm{E}$ (Fig. 1) was isolated that produced about 1000 mouse MLD per ml. in laboratory media (Dolman 1953; Dolman and Chang 1953).

During the period 1947-56 four outbreaks of botulism, all due to "muktuk", occurred at or near Kotzebue $\left(67^{\circ} \mathrm{N} .162^{\circ} 30^{\prime} \mathrm{W}\right.$.). The 8 affected Eskimos, of whom 5 died, were treated at the Alaska Native Hospital, Kotzebue. As Rabeau (1959) has reported these episodes, only their salient features will be outlined here. In July 1947 a 55-year-old man, his son aged 25, and his daughter-in-law aged 22 were admitted to hospital with severe symptoms of botulism, having eaten "muktuk" 16 hours before. The older man died about 50 hours and the young woman about 55 hours after the meal. The son eventually recovered, but was convalescent for $\mathbf{5}$ months. No food samples could be examined.

In August 1948 a 58 -year-old resident of Noatak $\left(67^{\circ} 30^{\prime} \mathrm{N} .163^{\circ} \mathrm{W}\right)$ ate 3 pieces of "muktuk". His 16-year-old son ate a single piece. Twelve 
hours later they developed symptoms of botulism, and after another 7 hours were admitted to hospital, where the man's condition grew worse despite administration of type $A$ and $B$ antitoxin. He died about 54 hours later. The boy recovered sufficiently to be discharged in 2 weeks. Again no samples were available for laboratory tests.

In July 1952 a 63-year-old male reached hospital with typical advanced botulism from a fishing camp near Selawik $\left(60^{\circ} 30^{\prime} \mathrm{N}\right.$. $160^{\circ} \mathrm{W}$.). Some 16 hours before the onset of illness he had eaten "muktuk". He died about 70 hours after consuming the suspected food, from a remnant of which a type $\mathrm{E}$ strain of $\mathrm{Cl}$. botulinum was isolated.

In August 1956 a Kotzebue woman, aged 46, and her 8-year-old daughter were admitted to hospital with symptoms of botulism, which began 16 to 18 hours after eating "muktuk". The mother died suddenly 8 days later, and the daughter eventually recovered from a serious attack. Her 10-yearold brother, who also ate some of the food, had only gastric disturbances. From a small sample of the implicated "muktuk", Meyer and Eddie (1956) isolated a strain of $\mathrm{Cl}$. botulinum type $\mathrm{E}$ (Dolman 1957a).

A fourth outbreak of type E botulism occurred at Scammon Bay $\left(62^{\circ} \mathrm{N}\right.$. $166^{\circ} \mathrm{W}$.), in October 1959. A boating party found the decomposed carcass of a grey whale, which had obviously been dead for some time. Many of the villagers did not heed warnings and ate portions of the flesh, feeding some to the dogs, without ill effects to man or beast. The fluke is prized for food, and next day 8 men ate various amounts of it uncooked. Within 24 hours 7 of them developed typical botulinic symptoms. Three were moderately ill, 4 severely, and one of the latter died on the third day. At the Regional Public Health Laboratory, Anchorage, unindentified toxin was demonstrated in extracts and cultures prepared from portions of the fluke (Pauls 1960).

Three samples from different parts of the fluke were forwarded to the author, along with some seal oil, the remains of a smoked salmon, and a sample of blood serum taken from the fatal case at autopsy. One of the fluke samples was non-toxic, another was slightly toxic, and the third contained between 200 and 600 mouse MLD of type E toxin per gram. From the last specimen a culture of $\mathrm{Cl}$. botulinum type $\mathrm{E}$ was isolated, whose in vitro toxigenic capacity was 1000 to 3000 mouse MLD per $\mathrm{ml}$. The salmon and the seal oil were atoxic, but the former yielded a type $\mathrm{E}$ strain whose toxigenic capacity was similar to that of the whale strain. The dead man's serum contained 3 mouse MLD per $\mathrm{ml}$. of type $\mathrm{E}$ toxin.

The salmon and seal oil had been suspected at first as possible vehicles, but later it was learned that 2 of the victims had not eaten the fish dipped in the oil, whereas all had eaten whale meat. The salmon and the fluke were never in contact with each other, nor had they been cached in the same spot; but there were many opportunities for both to have been exposed to exogenous contamination by any botulinus spores present in the marine silt of the area. This particular salmon was not decomposed, but in preparing "tipmuk" - a common type of food cache in this region - salmon are heaped 
into tightly enclosed pits lined with willow leaves and allowed to putrefy for at least one month. Then the material is used for both human and canine consumption (Philip 1960). Obviously "tipmuk" should be reckoned another potentially botulogenic Eskimo food.

A previous example of dual type $\mathbf{E}$ isolations during investigation of a single outbreak of botulism is afforded by the 1957 fatalities at Prince Rupert, B.C. Strains of similar characteristics were isolated from the implicated salmon eggs and from the stomach contents of one victim, but spores of an apparently distinct strain were present in a non-toxic sample of eulachon (Chinook = candlefish) oil found on the premises where the fish eggs had been prepared and eaten (Dolman 1960).

Nain and Hopedale, Labrador. In December 1956 an outbreak of botulism occurred among a hunting party of Eskimos at the sealing station of Ungadlek, some 35 miles east of Nain (roughly $56^{\circ} 30^{\prime} \mathrm{N}$. $61^{\circ} 30^{\prime} \mathrm{W}$.). At a noon meal 6 men and 2 girls, aged 6 and 8 years, ate some "utjak" that had been stored in an unclean metal cask for 10 days at a temperature range of $20^{\circ}$ to $40^{\circ} \mathrm{C}$. Within 24 hours the younger girl and 4 men had died of typical acute botulism. Another man died on the third day. The older girl and one man had vomited soon after the meal and recovered in hospital. A similar tragedy had occurred in this area in 1954, at which time the natives were warned of the dangers of eating rotten seal meat (Brocklehurst 1957).

"Utjak", a favourite dish among Eskimos in the Eastern Arctic, is traditionally prepared by placing seal flippers, complete with fur, in a wooden cask, which is left, covered with a lid, behind the stove for several days. In this instance an unwashed gasolene drum was used in which sealskins had been stored the year before. One of the remaining flippers, heavily coated with rancid seal oil, was forwarded deep-frozen to the author. The flesh contained 600-1000 mouse MLD per gram, and a strain of $\mathrm{Cl}$. botulinum type $\mathrm{E}$, capable of producing toxin of 1000-3000 mouse MLD per ml., was readily isolated from it (Dolman 1957a).

In May 1960 a similar outbreak occurred at Hopedale (approximately $55^{\circ} 30^{\prime} \mathrm{N}$. $60^{\circ} 30^{\prime}$ W.). Four Eskimo women ate rotting seal flipper that had been kept near a stove for some 10 days in a metal container. After about 24 hours 2 women, aged 49 and 18, developed abdominal cramps, vomiting, and diarrhoea, followed by epigastric pain, visual disturbances, and dysphagia. Both died in respiratory failure, the older woman within 48 hours of the meal, and the other a few hours later. Two other women, found to be suffering from gastrointestinal and visual disturbances, and dysphagia, were brought to hospital by helicopter, where type $\mathrm{E}$ antitoxin was administered intramuscularly. Both made a good recovery. No food samples were available for laboratory examination. A piece of liver, taken at autopsy, was forwarded deep-frozen to the author. A saline extract of this material contained no detectable botulinus toxin, and $\mathrm{Cl}$. botulinum could not be isolated from it.

Three weeks later, in June 1960, another fatality occurred at Hopedale. 
A woman, aged 35, was the sole consumer of some raw seal liver taken from a carcass that had lain in a warm porch-way for 3 days. Within 12 hours of the meal, she developed vomiting, diplopia, dry mouth, and dyspnoea. She died shortly before a physician arrived. A remnant of the implicated seal liver and the patient's stomach washings were relayed in dry ice to the author. Both specimens were atoxic, but the liver yielded a type $\mathrm{A}$ strain of $\mathrm{Cl}$. botulinum, which produced roughly 100,000 mouse MLD per ml. of culture medium.

In the same vicinity, 12 days later, a 59-year-old Eskimo male fell ill after eating dried seal meat. He died shortly after arrival in Hopedale. A sample of stomach washings was atoxic and proved bacteriologically negative. Within a few days dried seal meat caused another severe case at Hopedale. Type E antitoxin was administered after typical symptoms had been present for 24 hours, and the patient made an uneventful recovery. Finally, early in July 1960, a male recovered from botulism at Nain, the vehicle being seal flippers (Paddon 1960). In none of these last two instances were specimens available for laboratory examination.

The outbreaks cited do not represent all occurrences of botulism among Labrador Eskimos. In the past decade or so, according to Paddon (1960), persistence in eating "utjak", particularly among the older generation, has caused "a good many deaths". There are no recorded instances of botulism affecting the white man in the Arctic; but it may be recalled that the first known type E outbreak at Cooperstown, N.Y. in 1932 was due to Labrador salmon, probably caught and prepared near Cartwright. The fish had been smoked and coated with wax before being shipped and was not subsequently cooked.

\section{European occurrences}

Very few type $\mathrm{E}$ outbreaks and isolations have been reported from Europe. Apart from a few exceptional foci, spores of this type must be comparatively rare in the soil and adjacent seas of the continent.

Russia. After Kushnir's isolation of the prototype E strains from sturgeon caught in the Sea of Azov (Dolman and Chang 1953), only one account of a proven type $\mathrm{E}$ episode can be traced in the Russian literature. In 1938 at Leningrad $\left(60^{\circ} \mathrm{N} .30^{\circ} \mathrm{E}\right.$.) a man died after eating smoked herring, from remnants of which a type E culture was isolated (Zavadovskaya 1940). Earlier, Kurochkin and Emelyanchik (1937) had described 3 outbreaks of botulism in 1934 and 1935 on the northwest shores of the Caspian Sea, several hundred miles east of the Sea of Azov. In each instance the vehicle was salted uncooked meat and blubber from seals (Phoca sibirica), which the local inhabitants occasionally eat. The first outbreak at Astrakhan (roughly $46^{\circ} 30^{\prime} \mathrm{N}$. $48^{\circ} \mathrm{E}$.) affected 3 persons, of whom 2 died. In the earlier of 2 outbreaks at Guryev $\left(47^{\circ}\right.$ N. $52^{\circ} \mathrm{E}$.), which together caused 5 deaths, extracts of incriminated seal meat contained toxin unneutralized by type $A$ and $B$ 
antitoxin. The meat yielded a culture of $\mathrm{Cl}$. botulinum whose reported characteristics warrant its retrospective identification as a type $\mathrm{E}$ strain.

The latest review of botulism in the Soviet Union (Matveyev and Gannushkin 1958) states that type E spores (as well as type A, B and C) have been found in the soil of the USSR, but gives no localities. There is no reference to botulism as a problem of the Far North.

France. Prévot et al. (1951, 1952 a, b) reported 3 fish-borne botulism episodes in different parts of France, which they considered probably due to type $\mathbf{E}$ toxin, although proof was wanting. There were no clues to the sources of contamination. Since marine species were involved, spores could have been ingested by the fish in the Bay of Biscay, the English Channel, or wherever they were feeding before being caught. Alternatively, as the outbreaks were all inland, terrestrial pollution might have occurred anywhere between the coast and the places cited, which lie within a comparatively large area of France from around $43^{\circ}$ to $50^{\circ} \mathrm{N}$. The isolation by Prévot and Huet (1951) of a type E strain from the intestinal contents of a freshwater perch (Perca fluviatilis) taken from a pond south of Paris, suggests that spores of local telluric origin might be the source of trouble in some parts of the country. In a second survey Prévot and Brygoo (1953) isolated type A strains from the intestines of 3 out of 133 fish caught in the same area.

Denmark. In October 1951 an outbreak of botulism occurred at Frederiksberg, Denmark, due to uncooked vinegared herring, which yielded a type $\mathrm{E}$ culture. Six persons were severely affected, but none died. Subsequently, the presence of type $\mathrm{E}$ spores was demonstrated in 12 out of 15 sea mud specimens collected at depths of 3 to 6 metres from the fish market canal and other parts of Copenhagen harbour (Pedersen 1955).

Among 10 outbreaks of botulism recorded in Denmark over the period 1901-58, there have been 3 others in which the vehicle was uncooked fish. Whereas in the Frederiksberg episode every victim recovered, in these earlier instances all 9 affected persons died. Salted mackerel was implicated in one outbreak, and salted herring in the two others. The types of $\mathrm{Cl}$. botulinum involved were not identified (Jensen and Hahnemann 1959).

The Baltic and North Sea. Focal concentrations of type E spores may exist elsewhere around the shores of the Baltic Sea. For example, at Westchester County, N.Y., in 1934 typical botulism developed in 3 adults, one of whom died, after eating canned sprats ("Kielersprotten") imported from Kiel, Germany (Hazen 1937). The toxigenic organism isolated from them was shown later to be a type $E$ strain (Hazen 1938).

Type A spores are also apparently present in this vicinity. Wasmuth (1948) has recorded 30 cases of botulism in the 3-year period 1945-8, affecting inhabitants of Kiel and the surrounding areas of Schleswig, the usual vehicle being vinegared herring. In a few instances type $A$ toxin or organisms could be demonstrated in the implicated fish, or in stomach contents. 
By contrast, the North and Norwegian seas seem relatively free of botulinus spores. There is no record of such spores being identified in sea bottom or shore samples from these regions, perhaps because there have been few systematic attempts. An opportunity arose 2 or 3 years ago to examine in this laboratory samples of sea mud collected a few months earlier, at depths ranging from 140 to 400 metres, from subarctic and arctic fishing grounds in the Norwegian Sea. None of the 19 specimens yielded toxic cultures.

In the British Isles botulism due to locally caught fish is unknown. Two type A cases reported from England (Mackay-Scollay 1958) were due to fish caught and pickled in Mauritius 4 weeks before. In Norway, where much salted fish is consumed, out of a total of 10 occurrences to date only 2 inland episodes, each involving single individuals, have been fish-borne. The vehicle was "rakefisk", a Scandinavian dish in which trout (Salmo trutta), freshly caught in mountain lakes, are layered with salt under pressure in a wooden tub and stored in a cool place. Seven of these outbreaks (including the fish-borne ones) were due to type B toxin (Skulberg $1958,1960)$. The only plausible example of botulism traceable to North Sea fish is the recent type E case at Penticton, B.C.; but even here it is possible that the keg of salted Holland herring became contaminated in British Columbia, either during storage or while its contents were being prepared for consumption (Dolman 1961).

\section{Discussion}

This report poses two main problems. The first, mainly theoretical, relates to the peculiar geographic distribution of type $\mathrm{E}$ spores. The second is concerned with the practical steps necessary to avert dangers resulting from germination of botulinus spores in foodstuffs prepared from fish and marine mammals such as are consumed by the Eskimos and other natives of the Far North.

Cl. botulinum type $\mathbf{E}$, unlike types $\mathbf{A}$ to $\mathbf{D}$, is not known to have been isolated in the southern hemisphere. Indeed, the epidemiological evidence to date indicates that type $\mathrm{E}$ spores occur in significant numbers only at latitudes higher than $40^{\circ} \mathrm{N}$; ; and further, that their heaviest disseminations are in northern Japan, and in scattered foci along the northwest Pacific Coast, and the subarctic and arctic perimeter of North America. These restricted localizations provoke certain questions. What factors make the northern hemisphere, and particularly lands bordering the northern Pacific Ocean, especially liable to type E botulism? Why do not similar outbreaks occur, for instance, in Lapland or northern Siberia? And why are type $\mathrm{E}$ strains predominantly involved in botulism due to foodstuffs of marine origin? Partial answers to some of these questions have been offered previously, based on the supposition that type $\mathrm{E}$ spores, although telluric in origin, have a special affinity for the ocean floor, and for terraqueous deposits of the littoral in colder areas, where they may intermittently 


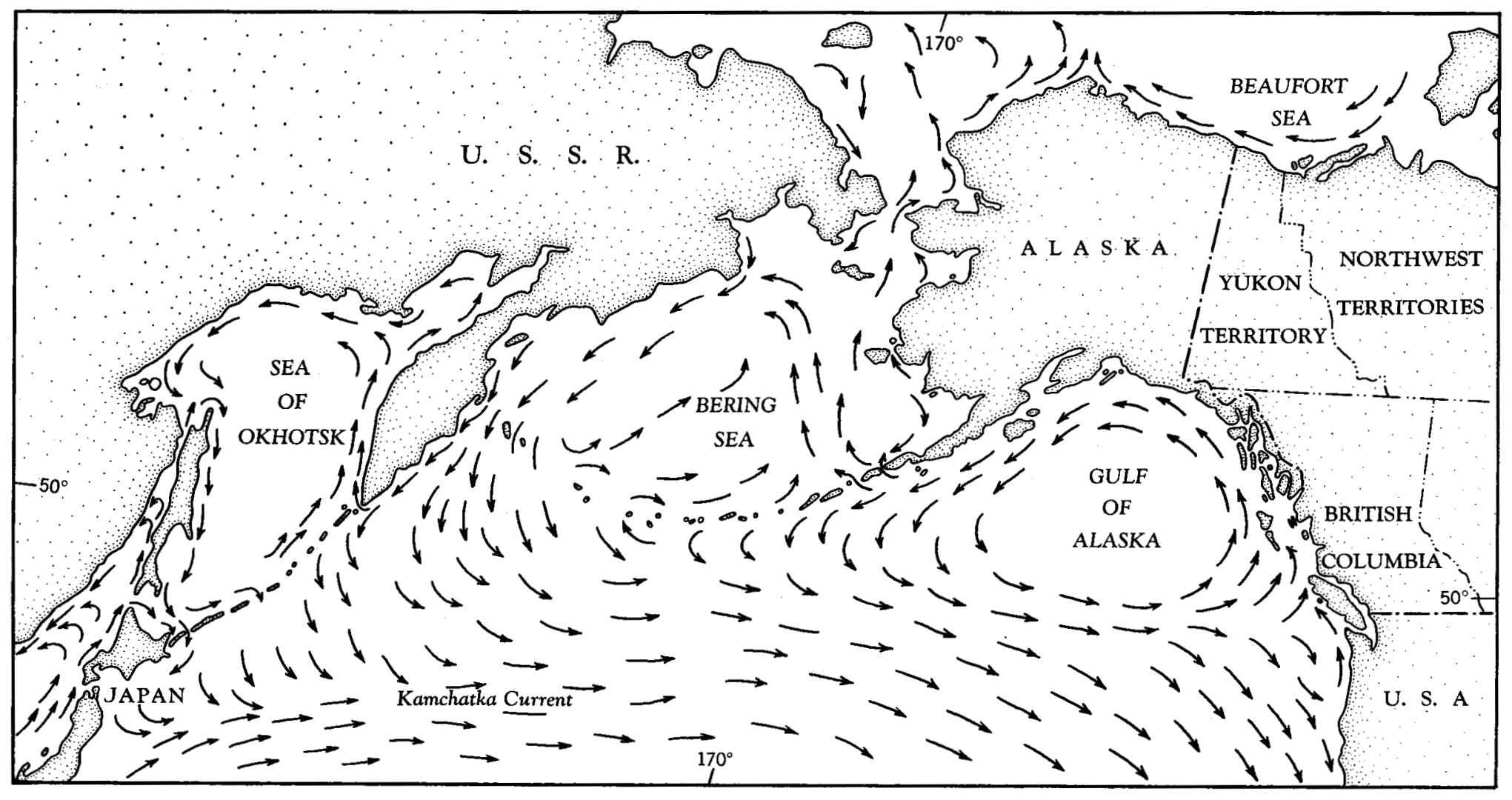

Fig. 4. North Pacific Ocean and contiguous seas, showing main currents in relation to continental land masses. 
germinate and proliferate (Dolman 1957b). This hypothesis, with some embellishment, still seems valid.

Ten years ago it was first noted (Dolman et al. 1950) that type $\mathrm{E}$ toxin can be produced at a temperature of $6^{\circ} \mathrm{C}$. Ohye and Scott (1957) showed further that type $\mathrm{E}$ strains grow and produce toxin over a temperature range $5^{\circ}$ to $10^{\circ} \mathrm{C}$. lower than do type $A$ and $B$ strains. These observations help to explain the tendency for type $\mathrm{E}$ botulism to preponderate in colder climates, and also to refute the claim of Abs (1959) that optimum temperatures for the growth of $\mathrm{Cl}$. botulinum are probably not attainable in arctic latitudes. It is perhaps unnecessary to add that Abs errs in asserting that "botulism has not yet been demonstrated in the Arctic".

The predilection of type $\mathrm{E}$ botulism for the northern hemisphere is no doubt due to various factors, ranging from the direction and velocity of ocean currents, and prevailing water and air temperatures, to the ecology of the causal microorganism and the dietetic customs of the inhabitants. Their interrelationships are too complex and uncertain for discussion now, but certain points seem relevant. The northern hemisphere comprises most of the world's land mass, and a correspondingly small proportion of ocean waters in which terrestrial spores can be dispersed. At higher latitudes, the ratio of land mass to water volume increases, especially in the Pacific area. Between the parallels $45^{\circ}$ and $50^{\circ} \mathrm{N}$. the widely separated coastlines of eastern Asia and western North America are linked by the well-marked Kamchatka Current, flowing eastward. Farther north, the great expanse of the Pacific Ocean narrows and is divided into the Sea of Okhotsk, the Bering Sea, and the Gulf of Alaska, all bordered by mountainous territory; and the uni-directional current traversing the main ocean merges with, or gives rise to, 3 separate regional currents circulating counter-clockwise within these lesser seas (Fig. 4). Finally, at the Bering Strait, where the continents almost touch, a north-flowing current skirts the coast of western Alaska.

Ohye and Scott (1957) deduced from the relatively low temperature range of type $E$ strains that their natural habitat is marine rather than terrestrial. In that event, they should differ - but do not - from type A and B strains in ability to survive in sea water, and in sodium chloride tolerance (see below). Nearly 40 years ago Meyer and Dubovsky (1922a) suggested type A botulinus spores had an affinity for the primordial soil of certain California mountain ranges. A comparable postulate for type $\mathrm{E}$ spores, combined with the above geographic and oceanographic considerations, helps to explain their presence in the sea mud, silt, or sand of areas where the incidence of type $\mathrm{E}$ botulism is high. Thus, the waters and terraqueous deposits surrounding the rugged island of Hokkaido, or encroaching upon the rainy, mountainous coastline of British Columbia and Alaska, are bound to reflect to an unusual degree the bacteriological flora of the nearby land. Germination and multiplication in marine and littoral foci where micro-environmental conditions are propitious could then account for the findings of Saito and Fujisawa (1956) and of Nakamura et al. 
(1956) that the concentration of type $\mathrm{E}$ spores in lagoon bottom mud and coastal sand may be much higher than in neighbouring soil. Spores can also be transported far and wide by tides and currents, or by fish and marine mammals which ingest and in due course excrete them, perhaps in substantially increased numbers. Thus, three mechanisms - the erosion of mountain slopes, the infiltration of sea water lapping the shore, and the migratory habits of fish and marine mammals - may convey spores to coastal areas at various distances from their origins, the final distribution patterns being determined largely by the course of rivers and streams, and by the flow of ocean currents and tides.

The foregoing hypotheses seem compatible with the known distribution of type $\mathrm{E}$ botulism in the northern Pacific and contiguous subarctic and arctic regions (see Figs. 4 and 5). They also permit some deductions about the likelihood of the disease occurring among other northern natives. For instance, the disseminations of type $\mathrm{E}$ spores in the littoral of Hokkaido and in adjoining parts of northern Honshu, may derive not only from inland mountains, but also from ranges on the Kamchatka Peninsula and adjacent areas of eastern Siberia bordering the Sea of Okhotsk; for the currents hereabouts are such as to encourage the scourings of this sea to be deposited on or near the coasts of northern Japan. Hence, type E botulism might well occur among the Kamchadals and any other native peoples of eastern Siberia who eat raw fish or marine mammals, though the disease could be as unrecognized there as it was in Japan until less than 10 years ago.

The concentration of spores in the vicinity of Prince Rupert, B.C., could be due to the northerly arm of the bifurcating Kamchatka Current intermingling here with the outflow of the Skeena River and the lesser tidal streams that drain the slopes of the Coast Mountains. The ultimate source of these spores therefore may have been thousands of miles away in Kamchatka, or perhaps only a few miles inland. Again, a current sweeping slowly northwards along the west coast of Alaska would tend to deposit spores in heaviest concentration near the Bering Strait bottleneck, i.e. along that very stretch of shoreline from Scammon Bay to Point Hope where all known outbreaks among Alaskan Eskimos have occurred. Since the opposite coast lies in the path of a contrary current flowing southward from the East Siberian Sea, it could escape being seeded with type E spores, so that botulism might be unknown among the Eskimos of the Chukotski Peninsula, despite dietetic customs similar to those prevailing across the Strait.

The liability of Labrador Eskimos to type E botulism probably derives from a similar complex of geographic, oceanographic, ecologic, and dietetic factors. The outbreaks in the Nain and Hopedale regions should be considered in relation to the isolation by Pedersen (1955) of a toxigenic type $\mathrm{E}$ culture from a sample of sea mud trawled from the bottom of Agluitsok Bay (about $60^{\circ} \mathrm{N} .45^{\circ} \mathrm{W}$.) on the southwest tip of Greenland. The suggestion has been made previously (Dolman 1957b) that these facts may be linked by the well-defined northerly current that washes the west coast of Greenland and 


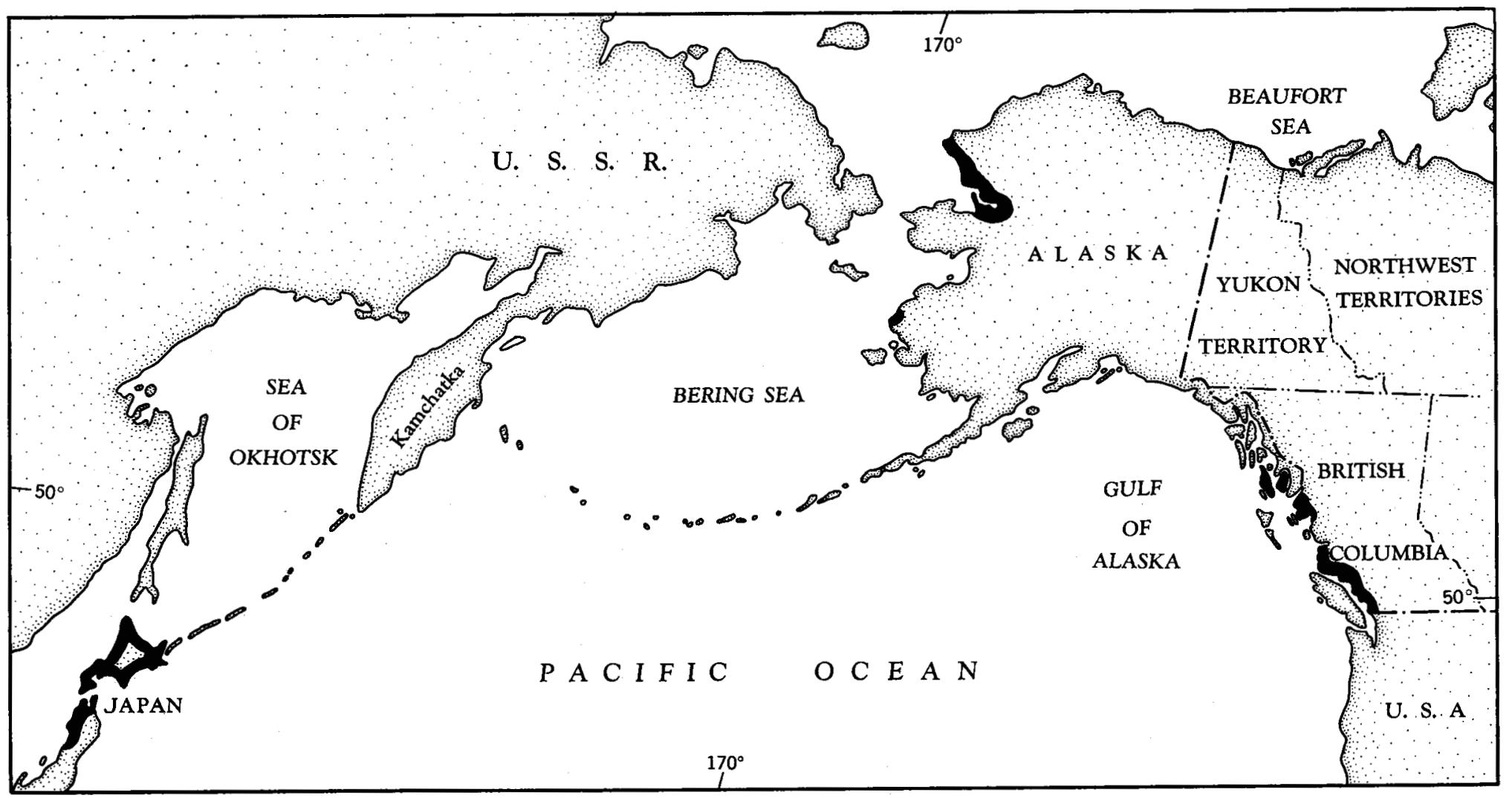

Fig. 5. Foci of endemic type $\mathbf{E}$ botulism due to consumption of raw marine foodstuffs, involving coastal fringes of northern Japan, British Columbia, and Alaska. Compare with Fig. 4. 
turns southward in Davis Strait to become the Labrador Current. Thereby type $\mathrm{E}$ spores from the mountains and fiords of southwest Greenland and of northeast Labrador could be picked up and deposited along the littoral a few hundred miles farther south. In other words, unless the western Greenland Eskimos have distinctive dietetic habits they may be exposed to the risk of type $\mathrm{E}$ botulism.

The absence of recorded botulism in northern Europe and Asia invites comment. Although the misadventures of distant native peoples do not always come to the attention of the central governments concerned, it seems improbable that the authorities in, e.g., Norway, Sweden, and Finland, would be unaware of the public health hazards faced by the Lapps. Nor is it likely that botulism endemic to the Siberian Arctic would pass unrecognized. "Fish poisoning" has been prevalent around the Caspian Sea, and its symptomatology discussed frequently in the Russian medical literature for over 100 years, and the botulinic nature of the disease has been known to Russian bacteriologists for half a century (Dolman and Chang 1953). Yet the diet of the inhabitants of the remote northern fringes of the USSR (such as the Skolts of Russian Lapland, the Chukchi of the northeastern Siberian Arctic, and the Kamchadals) does not lack botulogenic components. In a review of dietary habits in Finnish Lapland Latsky (1955) states that reindeer meat may be eaten uncooked in dried, smoked, or slightly salted form; and reindeer stomachs, filled with blood or milk, are buried in the snow or slowly dehydrated over a fire for several weeks or months before consumption of their contents. Raw fish is also eaten dried or smoked, or slightly salted and soured. On such a diet, if spores were as numerous in these parts of the world as they apparently are in the other areas cited, outbreaks of botulism would seem inescapable. As things are, it is necessary to postulate a paucity of all types of botulinus spores in the far northern littoral of Europe and Asia.

This postulate is consistent with the irregular distribution of type A and $B$ spores, recognized since the soil surveys of Meyer and Dubovsky (1922 a, b, c), and also with the evidence collected here pointing to variations in the incidence of type $\mathrm{E}$ spores. At present, regional telluric dearth or abundance of botulinus spores cannot be explained. However, it seems plausible to invoke geographic and oceanographic considerations again to account for the presumed failure of water-borne type $E$ spores to reach the arctic shores of these continents. Whereas northern Japan, western Alaska, and central Labrador are impinged upon by cold ocean currents, which have lapped the littoral of regions where the ratios of land mass to water volume are high, the reverse holds for the regions in question. The North Atlantic Drift Current, which passes tangentially up the Norwegian coast and turns eastward to skirt the Kola Peninsula, is relatively warm, mainly owing to its Gulf Stream component. Moreover, in its long northeasterly passage across the Atlantic and on through the Norwegian and Barents seas to the Arctic Ocean, this current is unimpeded by funnel-like convergences or massive interpositions of land, so that any spores carried 
by it would be subject to an extremely high dilution factor, as well as to comparatively scant opportunities for terrestrial settlement.

If a high incidence of type $E$ spores in the terraqueous deposits of certain parts of the Northern Hemisphere is accepted as a plausible explanation for the close association between type $\mathrm{E}$ botulism and marine products, the question naturally arises whether their preponderance over type $A$ and $B$ spores in such environments can be accounted for in terms of experimentally detectable differences in, e.g., ability to survive or to vegetate and proliferate in sea water. In a vain attempt to elucidate this possibility, several laboratory tests have been carried out, the details of which will be published elsewhere. In sum, the results showed no significant differences in the survival of heavy inocula of type $\mathrm{A}, \mathrm{B}$, and $\mathrm{E}$ spores in sterilized sea water kept at $3^{\circ}$ to $5^{\circ} \mathrm{C}$; no definite decline in numbers of viable spores after 80 days; and possibly some occasional proliferation (regardless of type) during this period. In another series of experiments, spores were able to vegetate and multiply at $30^{\circ} \mathrm{C}$. in appropriate media containing up to 4 to 6 per cent $\mathrm{NaCl}$, and under these conditions equal tolerance to sodium chloride was shown by the 3 types of spores.

A problem of prime importance remains for brief discussion, viz., the possible means of reducing or eliminating the hazard that endemic botulism presents to certain native peoples of the Far North, especially the Eskimos. In the 12 months preceding compilation of this report, of no fewer than 9 outbreaks coming to the author's attention, 2 were among Indians in southeastern Alaska, and 6 affected Eskimos in Labrador and northwestern Alaska. There were 8 deaths among a total of 18 affected natives. This was apparently an exceptional year, but such figures probably reflect the actual incidence of the disease more nearly than do those previously reported. Theoretically, control measures (none of them easily applied) range from the overthrow or modification of long established dietary customs to the induction of specific immunity. Endemic type E botulism is most likely to occur in localities where type $\mathrm{E}$ spores abound and where the people prefer to eat their sea foods raw. Since the spores cannot be dispersed, protection is only possible through changes in food habits.

Type $\mathrm{E}$ spores and all types of botulinus toxins are destroyed by moderate heat. A foodstuff heated throughout to $80^{\circ} \mathrm{C}$. for 30 minutes, or to $100^{\circ} \mathrm{C}$. for 10 minutes, will contain few if any viable type $\mathrm{E}$ spores and little or no type A, B, and E toxin. Indeed, these toxins are so thermolabile (Prévot and Brygoo 1953) that intimate exposure of all parts of a butolinic food for only a few minutes to $60^{\circ} \mathrm{C}$. should reduce the toxicity to insignificant levels. However, type A and B spores (especially the former) whose occasional involvement in botulism among Eskimos and Indians has been illustrated are usually very heat resistant. Hence, aside from inherent risks of recontamination with type E spores, a foodstuff such as "muktuk", heated to the above extent, but subsequently immersed in seal oil for several days or weeks, could not be reckoned safe. These foods can be made safe only by sufficient heating very shortly before their consumption. For the Eskimos, an added 
advantage of this heat treatment would be protection against trichinosis.

The proposed violation of time-honoured recipes may be rejected by these natives because the desired flavour will be lost; it may be scorned in defiance of the white man's encroachments and paternalism; or ignored when fuel is scarce, time short, and hunger rampant. But since type $\mathrm{E}$ organisms are nonproteolytic, foods containing dangerous amounts of type $\mathrm{E}$ toxin may be unaltered in taste, odour, or appearance. Moreover, neither gustatory discrimination nor self-inflation guarantees longevity. In time, acculturation will change the picture, but meanwhile it should be made clear to those concerned that mortal dangers may lurk in some of their traditional foods. The responsibility for translating this advice into simple, forceful terms rests with public health and other responsible officials.

Refrigeration, whether natural or mechanical, must be ruled out as an alternative method of temperature control in this context. Natural refrigeration is unreliable and impracticable, even for Eskimos. In winter, seal carcasses are liable to be stored inside dwelling-places, "utjak" even being kept near a stove to mature. In summer or early autumn, when most of these botulism outbreaks occur, quite high outdoor temperatures may prevail along the Alaskan and Labrador coasts. Mechanical refrigerators, apart from being at present out of reach of the average Eskimo and Indian, would not guarantee protection, since type $\mathrm{E}$ toxin can be produced at a temperature as low as $6^{\circ} \mathrm{C}$.

$A$ useful degree of active immunization against type $A, B$, and $E$ botulism could probably be accomplished by inoculating populations at risk with trivalent botulinus toxoid. However, this is impracticable, owing to the difficulties of administering multiple doses at suitably spaced intervals to scattered and often migratory groups of all ages. On the other hand, administration of botulinus antitoxin could be life-saving, provided the appropriate serum was given soon after the onset of symptoms. A small quantity of type $\mathrm{E}$ antitoxin, prepared by the Connaught Medical Research Laboratories, University of Toronto, in co-operation with the Defence Research Board of Canada, has been made available for clinical trial in suitable areas. In five cases treated with this antitoxic serum - two in northern Japan and three in Labrador - the results were very encouraging. Such a monovalent preparation can only be effective against an intoxication of homologous type. The form of botulism under review is generally, but not exclusively, due to type $\mathrm{E}$ toxin, and the need seems urgent for supplies of trivalent botulinus antitoxin to be manufactured and kept accessible in regional depots where the disease is endemic.

Detailed discussion of the specific and symptomatic treatment of botulism would not be appropriate in this paper. But a few final comments seem pertinent on what should be done when the disease strikes in e.g. an Eskimo settlement. Any case of suspected botulism should be regarded as an emergency, requiring prompt hospitalization with transportation of the affected persons by air, regardless of cost. Pending the arrival of plane or helicopter, equipped if possible with a mechanical respirator, the most 
important first aid measure is to empty and thoroughly irrigate the stomach. In the absence of doctor or nurse, the nearest missionary, teacher, or policeman who knows how to pass a stomach tube should carry out this procedure, using an alkaline solution such as 2 to 5 per cent sodium bicarbonate in water. The 3-fold purpose is: to evacuate botulinic material not yet absorbed; to expose unabsorbed toxin to alkaline $\mathrm{pH}$ levels, at which all types of botulinus toxins become unstable; and to minimize the tryptic activation process, primarily affecting type $\mathrm{E}$ toxin, whereby in the presence of trypsin at a $\mathrm{pH}$ range of 5.5 to 6.5 , the lethal potency of this toxin undergoes a manifold increase for mice and men (Dolman 1957b). This last-mentioned property of type $\mathrm{E}$ toxin no doubt contributes to the special element of unpredictability about the outcome when botulism attacks the inhabitants of northern Japan or the coastal Indians and Eskimos of North America.

\section{Summary and Conclusion}

Botulism due to consumption of uncooked products of fish and marine mammals occurs endemically in certain regions of the northern hemisphere. Type E strains of Clostridium botulinum are usually involved. Since this microorganism was identified 25 years ago, 50 outbreaks of type $\mathrm{E}$ botulism have been reported, affecting 242 persons, of whom 85 died - an overall case fatality rate of 35.1 per cent. About three-fifths of these outbreaks, involving roughly three-quarters of the total cases and deaths, have been recognized within the last decade in northern Japan, where fermented rice cakes containing raw fish ("izushi") have been almost exclusively implicated.

Four of the remaining proven type $\mathrm{E}$ outbreaks have affected coastal Indians of northern British Columbia and southeastern Alaska, the vehicle being raw salmon eggs prepared and stored insanitarily. In 5 episodes, Alaskan or Labrador Eskimos have been attacked, following consumption of beluga flippers ("muktuk"), whale fluke, or seal flippers ("utjak"). There are several additional reports of botulism among these North American native groups, based on clinical and epidemiological evidence but lacking bacteriological confirmation; and hearsay evidence indicates that many other cases have gone unreported. In the last 15 years traditional Eskimo foods prepared from marine mammals have proved botulogenic in 13 outbreaks, altogether involving 44 persons, aged 6 to 59 years, of whom 23 died ( 52.3 per cent). This form of botulism is a more hazardous disease than arctic trichinosis, with which it may have been confused at times, despite few resemblances. Since adequate heating of such foods shortly before consumption alone ensures their safety, control of the disease presents a major challenge in public health education, particularly among the Eskimos ("those who eat raw flesh").

Supplies of trivalent botulinus antitoxin of type A, B and E, should be made available in endemic areas for emergency use. Encouraging results 
have been obtained in a few cases treated with type $E$ antitoxin, but the monovalent product would be useless in the occasional type $A$ or type $B$ outbreak due to raw marine products, of which single instances are cited. Thorough stomach washing with sodium bicarbonate solution is suggested as an important first aid measure.

Oceanographic and other factors are discussed that seem to determine the peculiar distribution of type $\mathbf{E}$ spores in sea mud and other terraqueous deposits of the littoral in northern Japan and in arctic and subarctic regions of North America. Heavy disseminations of such spores in these areas, combined with very botulogenic dietary habits among the local natives, account for and are believed to justify the title of this review.

\section{Acknowledgements}

Besides those whose communications are referred to in the text, the following persons have co-operated in various ways. Dr. J. E. Josephson, Director of Laboratories, Department of Health, Newfoundland; Dr. R. N. Philip, Chief, Epidemiology Section, and Mr. F. P. Pauls, Bacteriologist, Arctic Health Research Center, Anchorage, Alaska; Dr. R. B. Williams, Director, Public Health Laboratories, Alaska Department of Health; and Dr. A. Roundhill, the International Grenfell Association, Labrador, provided data on outbreaks and forwarded specimens. Dr. G. L. Pickard, Director, Institute of Oceanography, University of British Columbia; Dr. J. M. Shewan, Director, Torry Research Station, Aberdeen; and Mr. M. R. Rondelet, Skeena Health Unit, Prince Rupert, B.C., procured sea bottom samples. Misses M. Tomsich, L. Murakami, and J. Colosimo, and Mr. C. C. R. Campbell, rendered valuable technical assistance; and Mrs. M. Irving prepared the maps. All this help is gratefully acknowledged.

\section{References}

Abs, O. 1959. Die Eskimoernährung und ihre gesundheitlichen Auswirkungen, Leipzig: G. Thieme, 107 pp. (Sammlung zwangloser Abhandlungen aus dem Gebiet der inneren Medizin. Heft 7. Herausgeber: Prof. Dr. G. Katsch).

Brandly, P. J., and R. Rausch. 1950. A preliminary note on trichinosis investigations in Alaska. Arctic 3:105-7.

Brocklehurst, J. C. 1957. Fatal outbreak of botulism among Labrador Eskimos. Brit. Med. J. 2:924.

Brown, M., B. Cronk, F. de Sinner, J. E. Green, J. E. Gibbons, and E. KuitunenEkbaum. 1949. Trichinosis on Southampton Island, N.W.T. Canad. J. Pub. Health 40:508-13.

Connell, F. H. 1949. Trichinosis in the Arctic: a review. Arctic 2:98-107.

Dolman, C. E. 1953. Human botulism in Canada. Canad. Med. Ass. J. 68:538-43.

48:187-98.

1957a. Recent observations on type E botulism. Canad. J. Pub. Health

1957b. Type E (fish-borne) botulism: a review. Japan J. Med. Sci. and Biol. 10:383-95.

(In press).

1961. Further botulism episodes in Canada. Canad. Med. Ass. J. 
Dolman, C. E., and H. Chang. 1953. The epidemiology and pathogenesis of type E fishborne botulism. Canad. J. Pub. Health 44:231-44.

Dolman, C. E., H. Chang, D. E. Kerr, and A. R. Shearer. 1950. Fish-borne and type E botulism: two cases due to home-pickled herring. Canad. J. Pub. Health 41:215-29.

Dolman, C. E., G. E. Darby, and R. F. Lane. 1955. Type E botulism due to salmon eggs. Canad. J. Pub. Health 46:135-41.

Dolman, C. E., and D. E. Kerr. 1947. Botulism in Canada, with report of a type E outbreak at Nanaimo, B.C. Canad. J. Pub. Health 38:48-57.

Dolman, C. E., M. Tomsich, C. C. R. Campbell, and W. B. Laing. 1960. Fish eggs as a cause of human botulism. Two outbreaks in British Columbia due to types $\mathbf{E}$ and $\mathbf{B}$ botulinus toxins. J. Infect. Dis. 106:5-19.

Fay, F. H. 1960. Carnivorous walrus and some arctic zoonoses. Arctic 13:111-22.

Gunnison, J. B., J. R. Cummings, and K. F. Meyer. 1936. Clostridium botulinum type E. Proc. Soc. Exper. Biol. and Med. 35:278-80.

Hazen, E. L. 1937. A strain of B. botulinus not classified as type A, B or C. J. Infect. Dis. 60:260-4.

1938. Incitants of human botulism. Science 87:413-4.

Iida, H., Y. Nakamura, I. Nakagawa, and T. Karashimada. 1958. Additional type E botulism outbreaks in Hokkaido, Japan. Japan J. Med. Sci. and Biol. 11:215-22.

Iida, H. 1959-60. Personal communications.

Jensen, B. B., and F. Hahnemann. 1959. Botulism. Reports of two similar epidemics. Ugeskr. Laeger. 121:1363-8. (In Danish).

Kurochkin, B., and K. Emelyanchik. 1937. Seal meat as a source of botulism. Vopr. pitan. No. 1, 141-8. (In Russian).

Latsky, J. M. 1955. Dietary habits in Finnish Lapland. Some personal investigations. S. Afr. Med. J. 29:794-6.

Mackay-Scollay, E. M. 1958. Two cases of botulism. J. Path. and Bact. 75:482-5.

MacKenzie, G. M. 1934. Three cases of botulism treated with antitoxin. Clinical Miscellany, Mary Imogene Bassett Hospital, Cooperstown, N.Y. 1:53-63.

Matveyev, K., and M. Gannushkin. 1958. Botulism. Bol'shaya Medits. Entsiklop. 4:266-87. (English trans. from Office of Technical Services, U. S. Dept. of Commerce, Washington, D.C.).

Meyer, K. F. 1950. Personal communication.

Meyer, K. F., and B. J. Dubovsky. 1922a. The distribution of the spores of B. botulinus in California. 1922b. . . . in the United States. 1922c. . . . in Belgium, Denmark, England, the Netherlands and Switzerland. J. Infect. Dis. 31:41-55, 59-94, 100-109.

Meyer, K. F., and B. Eddie. 1951. Perspectives concerning botulism. Zeit. f. Hyg. 133:255-63.

1956. Personal communication.

Nakamura, Y., H. Iida, K. Saeki, K. Kanzawa, and T. Karashimada. 1956. Type E botulism in Hokkaido, Japan. Japan J. Med. Sci. and Biol. 9:45-58.

Ohye, D. F., and W. J. Scott. 1957. Studies in the physiology of Clostridium botulinum type E. Austral. J. Biol. Sci. 10:85-94.

Paddon, W. A. 1960. Personal communications.

Parnell, I. W. 1934. Animal parasites of North-East Canada. Canad. Field-Naturalist 48:111-5.

Pauls, F. P. 1960. Personal communications.

Pedersen, H. O. 1955. On type E botulism. J. App. Bact. 18:619-28.

Philip, R. N. 1960. Personal communication.

Prévot, A.-R., and M. Huet. 1951. Existence en France du botulisme humain d'origine pisciaire et de Cl. botulinum E. Bull. de 1'Acad. Nat. de Médecine. 135:432-5.

Prévot, A.-R., M. Huet, and A. Thévenard. 1952. Second cas français de botulisme d'origine pisciaire. Bull. de l'Acad. Nat. de Médecine 136:323-4. 
Prévot, A.-R., J. Loiseau, and A. Thévenard. 1952. Nouveau cas de botulisme humain d'origine pisciaire. Résultat du traitement par l'anatoxine E. Bull. de l'Acad. Nat. de Médecine 136:663-4.

Prévot, A.-R., and E. R. Brygoo. 1953. Nouvelles recherches sur le botulisme et ces cinq types toxiniques. Ann. Inst. Past. 85:544-75.

Rabeau, E. S. 1959. Botulism in Arctic Alaska. Report of 13 cases with 5 fatalities. Alaska Medicine 1:6-9.

1960. Personal communications.

Saito, S., and S. Fujisawa. 1956. Studies on cases of botulism in Akita Prefecture. Epidemiological. Report No. 1. Akita Prefect. Med. J. 8:1-5. (In Japanese).

Skulberg, A. 1958. A case of fish-borne type B botulism. Nord. Hyg. Tidskr. 39:133-6. 1960. Personal communications.

Stefánsson, V. 1914. The Stefánsson-Anderson Arctic Expedition: preliminary ethnological report. Anthropol. Papers Am. Mus. Nat. Hist. 14:449.

1929. My life with the Eskimo. New York, Macmillan Co. pp.32-3.

Thorborg, N. B., S. Tulinius, and H. Roth. 1948. Trichinosis in Greenland. Acta Path. et Microbiol. Scand. 25:778-94.

Williams, R. B. 1960. Personal communication.

Yamamoto, K. 1960. Personal communication.

Zavadovskaya, T. A. 1940. Typing of a strain of Bacterium botulinum isolated from a case of food poisoning. Zhur. mikrobiol. epidem. immunol. No. 4, 59-63. (In Russian). 